\title{
alphauille
}

\section{Who's Got the "Reel" Power? The Problem of Female Antagonisms in Blaxploitation Cinema}

\author{
Melissa DeAnn Seifert, University of Wisconsin-Milwaukee
}

\begin{abstract}
Between 1973 and 1975, films starring Pam Grier and Tamara Dobson such as Cleopatra Jones (Jack Starrett, 1973), Coffy (Jack Hill, 1973) and Foxy Brown (Hill, 1974) introduced leading black women into the predominantly male blaxploitation scene as aggressive action heroines. Within the cinematic spaces of blaxploitation films which featured women as active agents, a racial and sexual divide exists. These films positioned women either inside or outside of gender tolerability by utilising binary constructions of identity based on race, sex and elementary constructions of good and evil, black and white, straight and gay, and feminine and butch. Popular representations of lesbianism and sisterhood within blaxploitation cinema reflect a dominant social view of American lesbianism as white while straight women are consistently represented as black. However, these spaces also constricted black and white female identities by limiting sexuality and morality to racial boundaries. This article seeks to question the unique solitude of these female heroines and interrogate a patriarchal cinematic world where sisterhood is often prohibited and lesbianism demonised.
\end{abstract}

I don't believe in [women's lib] for black people ... we're trying to free our black men ... I like being a woman. I have been discriminated against, but not because I'm a woman. It's because I am black ... before [people] see me as being female, they see me as being black. The stigma that's been placed on you because you're black gives you enough kill to get you through the woman thing ... it's much tougher being black than being a woman. (Tamara Dobson 1973)

Tamara Dobson, upon the release of Cleopatra Jones (Jack Starrett, 1973), expressed her disinterest with the women's movement, arguing that her action heroine character in the film was "not a women's libber" but was rather "defending an important freedom for her people: the freedom to exist without drugs" (Klemesrud). In contrast, cultural race theorist Michele Wallace wrote in a 1975 article entitled "A Black Feminist's Search for Sisterhood" about her quest for sisterhood and feminism: "the message of the Black Movement was that I was being watched, on probation as a black woman, that any sign of aggressiveness, intelligence, or independence would mean that I'd be denied even the one role still left open for me as 'my man's woman"' (67). She argued that "the most popular justification Black women had for not becoming feminists was their hatred of white women", a distinction that pleased black men (7). It is clear that black women identified in varying ways with the Black Power and women's liberation movements. An analysis of 1960s and 1970s blaxploitation productions exemplifies this general male interest in demoting female camaraderie by emphasising difference based on race, moral and sexual preference. 
In her autobiography Taste of Power: A Black Woman's Story, Black Power activist and former chairperson of the Black Panther Party, Elaine Brown recalls that many men in the Party were sure that she was a "man-hating lesbian" (367). She adds:

Oddly, I had never thought of myself as a feminist. I had even been denounced by certain radical feminist collectives as a "lackey" for men ... Resenting this label, I had joined the majority of black women in America in denouncing feminism. It was an idea reserved for white women. (367)

Brown's reasoning for rejecting feminism mimics Dobson's and reflects a reality of conscious division between women of varying races. Further, Brown adds that, by labelling her a "manhating lesbian", men were "not talking about making love with women" but attacking her "for valuing women" (367). It is apparent that the men to whom Brown refers saw female solidarities as problematic. If we can better understand the complex position of black women who, as Brown suggests, felt excluded in the expanding middle-class white feminist movement, then a clearer conception of the Black Power movement can be attained (367). In this vein, I argue that close observation of blaxploitation cinema exposes contested relations between women.

The Black Power movement of the late 1960s and 1970s influenced modes of representation in a variety of media. Mid-century black theorists, writers, poets, activists and musicians built upon on a tradition of earlier black power leaders such as Martin Delaney, W.E.B DuBois, Marcus Garvey, Ella Baker, Booker T. Washington, Frederick Douglass and, later, Malcolm X and Martin Luther King Jr. to create a new movement promoting a greater black consciousness (Van Deburg 19). These leaders challenged racial inequality and theorised about the problems associated with black experience in the United States. This in turn led to a new racial awareness and appreciation for blackness in America in which civil rights leaders and cultural nationalists refused white aesthetic superiority. Phrases such as "black is beautiful" indicated the adoption of a new pride in blackness itself (Peiss 258). Natural hairstyles and fashions inspired by distinctly African patterns and motifs began to emerge and inform an Afrocentric style that visually affirmed African heritage. Michele Wallace argues that "vision, visuality, and visibility" became much more important to the problematic aspects of a larger African-American discourse, especially as it related to issues of gender, sexuality and popular culture (Dark Designs 186). The continued rise of television as a medium in the 1960s helped ensure that visuality and imagery claimed a central position in American life. In the 1970s a new trend emerged that accentuated the hyper-masculinity of men in black action films, commonly referred to as blaxploitation films.

According to film theorist Ed Guerrero, blaxploitation could refer to any number of examples in American history in which black people have been exploited by whites. The term has been contested by a number of scholars as well as actors and actresses who worked in these films. ${ }^{1}$ Here the term will be used in its narrowest sense, to describe films that targeted "the black audience with a specific product line of cheaply made, black-cast films shaped with the 'exploitation' strategies Hollywood routinely uses to make a majority of its films" (69). Guerrero further refines the term to refer to the various action-adventure films set primarily in sensationalised ghetto environments that were released from approximately 1969 to 1975 . These include Shaft (Gordon Parks, 1971), Foxy Brown (Jack Hill, 1974), Cleopatra Jones, Super Fly 
(Gordon Parks Jr., 1972), Dolemite (D’Urville Martin, 1975) and Sweet Sweetback's Baadasssss Song (Melvin Van Peebles, 1971), among others (69). The extensive white tradition of visual caricaturising, which relied on degraded stereotyping and essentialist notions of blackness - most frequently citing Aunt Jemima, Sambo, Mammy, Sapphire and Uncle Tom-began to collapse. Blaxploitation exploited a young black audience by creating low-budget films with narratives targeting the interests of that audience (Lawrence, Blaxploitation Films 22-3). The genre was facilitated by a rising black consciousness, which, as Guerrero notes, "translated into a large black audience thirsting to see their full humanity depicted on the commercial cinema screen" (72).

Blaxploitation films of the 1960s and 1970s were essential in the reconstruction of black identity by visibly altering representations of blackness. They employed four commonalities: early films featured a socially and politically conscious black hero who was usually male; the male protagonist almost always worked independently; he was hyper sexualised and had numerous sexual partners simultaneously; and he specifically attacked individuals, rather than larger institutions or systems as the source of his oppression. These films revealed a new image of black individuality and power, targeting a young black male audience with low budget, mostly black cast films which ensured high profits for white producers and investors (Guerrero 68). Black women usually acted in passive, secondary roles as "bitches" or "hoes", reflecting gendered hierarchies and sexual power relations within the black community. However, between 1973 and 1975, Pam Grier and Tamara Dobson entered the blaxploitation scene as aggressive action heroines. Many other black actresses also found work in the genre, but they often played minor roles in less highly regarded movies. Therefore, much scholarly discourse is specific to Grier and Dobson rather than to the collective representation of women in the genre.

A few scholars have focused on gender and blaxploitation, drawing attention to masculinities and femininities, sexual dynamics and sexist representations, as I will illustrate in the following section. However, these sources have not addressed the important issue of women as inherently antagonistic within blaxploitation cinema. Films featuring women as active agents, I argue, often create a divide between female characters and deny gender-based solidarity. These filmic spaces separate women by distinctively positioning them within carefully constructed binary identities that are racially, sexually and morally coded. They contrast white, butch, lesbian, villainous characters with black, feminised, straight, heroic counterparts. This common trope promoted antagonistic relations between women, clearly marking their differences and reinforcing the impossibility of their coalition. When lacking lesbian and straight characters, then, directors simply added female fight scenes to display antagonism. I argue that ultimately these films, which were supposed to provide "reel" power for women, in truth empowered men, who arguably benefited from the films' anti-sisterhood message, especially as the women's liberation movement gained strength. Observing certain women in these films within the greater frame of the Black Power and women's liberation movements will clarify overlooked issues regarding representations of sexuality, gender and race, where these identities were used to weaken rather than strengthen female solidarities. 


\section{Scholarly Discourse and "Queer Blaxploitation"}

The classic era of blaxploitation cinema is understood to have ceased by 1979, despite arguments for a renewed focus on black films in the 1990s. For example, some scholars argue that films such as Do the Right Thing (Spike Lee, 1989), New Jack City (Mario Van Peebles, 1991), Boyz $n$ the Hood (John Singleton, 1991) and Dead Presidents (Allen Hughes, 1995), among others, are neo-blaxploitation films (Guerrero 1993; Brody 1999). Scholarship in both fields is fairly recent; in fact, many early blaxploitation scholars only began writing in the 1980s and early 1990s. Their work centred on black men and masculinity, while authors commonly dismissed the role of women and the films' reception by female spectators. As later scholars began to analyse women as crucial actors, figures such as Grier and Dobson were problematised for paradoxically acting as both heroines and sex objects.

Another strand of scholarship, while much less conspicuous, positions blaxploitation cinema within queer theory. A number of scholars mention villainised lesbianism in blaxploitation. For example, Harry Benshoff and Sean Griffin point to queerness in blaxploitation cinema as "functioning in opposition to the hero or anti-hero", whereas some films "equate homosexuality with a corrupt white culture" (146). Novotny Lawrence adds a useful analysis of Mommy, the lesbian villain in Cleopatra Jones, noting that her character mimics the "mammy" archetype while symbolically altering the role so that Mommy acts as "an evil lesbian matriarch rather than a warm and jolly caregiver" ("Cinema of Contradictions" 117). The author concludes that this shift produces a problematic depiction of lesbians (in this case, compared to a "tall, thin, and attractive" Cleopatra) as inherently deviant, ugly and threatening to heterosexuality (117-18). In The Girls in the Back Room, Kelly Hankin examines two of Grier's films, Foxy Brown and Sheba Baby (William Girdler, 1975), both of which feature problematic depictions of lesbian bars (81-113). Stephane Dunn ("Baad Bitches") and Yvonne Sims (Women of Blaxploitation; "From Headscarves to Afros") also wrote on the topic. In "From Headscarves to Afros", Sims notes the commonality of confrontation between white lesbian villains and black straight heroes, concluding that "negative portrayals [of lesbians] underlined the multifaceted aspects of African-American womanhood" (24). While this assertion rightfully points out how unfavourable representations of white lesbians worked to promote black femininity, it overlooks how these contestations were used to assemble seemingly insurmountable differences and thereby dismiss female camaraderie. Both Dunn and Sims problematise depictions of lesbianism, but omit a full analysis of sisterhood.

In his essay "Beyond the Black Macho: Queer Blaxploitation", Joe Wlodarz explores the "crisis of masculinity" manifest in 1970s blaxploitation cinema (1). He refers to Amiri Baraka's statement that "most American white men are trained to be fags", in order to point to the repeated characterisation of the "gay (and always feminised) white man" in blaxpoitation cinema (3). While Wlodarz's article focuses specifically on the queer images in blaxploitation that assign gayness to whiteness, the author never mentions lesbianism. His emphasis is on white, gay men in juxtaposition with black macho (straight) men. He argues that "black cinema constantly returns to the signifying power of the black male body in order to establish black male dominance over white men", who are "aligned with weakness and femininity" (5). This statement, while lacking reference to women, reflects a possible reason for prominent representations of white "evil" lesbianism (and female antagonisms alike) in blaxploitation. If 
Wlodarz's argument can be transposed to films with female leads, it is possible that white lesbian characters in films like Cleopatra Jones, Foxy Brown and Black Mama, White Mama (Eddie Romero, 1973) represent, through their association with weakness and with masculinity, transgressive characters who end up reinforcing the black female body. In other words, black female protagonists' femininity is enhanced when opposed to white, butch lesbian characters, in the same way as black male protagonists' masculinity is magnified when juxtaposed with white gay characters.

The aforementioned scholars observe gayness or lesbianism within blaxploitation films, but none extend their study to include the more general problem of a nonexistent sisterhood. The following analysis includes films such as Black Mama, White Mama, Coffy (Jack Hill, 1973) and Cleopatra Jones and the Casino of Gold (Charles Bail, 1975), in addition to Cleopatra Jones, Foxy Brown and Sheba Baby, in order to exemplify a filmic trend of female antagonisms and anti-sisterhood in blaxploitation. While other actresses, such as Teresa Graves (Get Christie Love!, William A. Graham, 1974) and Jeanne Bell (T.N.T. Jackson, Cirio H. Santiago, 1974), acted in similar action-heroine roles, this study will specifically refer to films featuring Dobson and Grier in order to concisely analyse each film's contribution to themes of contentious female relations. $^{2}$

The intersections of lesbianism, femininity, race and morality need to be fully examined in these films. Both Dobson and Grier's films present racialised lesbianism as linked to a binary struggle between good and evil and pit women against one another without apparent reason. In an attempt to analyse these identities and gender relations, it is useful to focus on 1960s and 1970 s conceptions of lesbianism and womanhood in both the white and black communities. Before turning to the films, female sexuality and lesbianism should also be examined within the context of Black Power groups (especially those under male leadership) such as the Black Panther Party and the Student Non-Violent Coordinating Committee (SNCC).

\section{Black Power and Women's Power: Overlapping Struggles for Equality}

Huey P. Newton, co-founder of the Black Panther Party, approved of and endorsed solidarity with the LGBT community. In a 1970 speech, Newton declared that "homosexuality is a fact that exists, and we must understand it in its purest form: that is a person should have the freedom to use his body in whatever way he wants", concluding that "we should form a working coalition with the gay liberation and women's liberation groups" (153-6). Newton's specific adherence to men's sexual freedom is apparent, notably avoiding the subject of women's sexual liberation. In its entirety, his speech reflects a division between gay people and women, ignoring the possibility of lesbianism. He condones white male homosexuality and straight white women's liberation, but only as separate issues; his feelings about black lesbianism are not vocalised. Similar attitudes were prevalent in the Black Power movement. Eldridge Cleaver, outwardly identified as homophobic, asserted that "I, for one, do not think that homosexuality is the latest advance over heterosexuality on the scale of human evolution. Homosexuality is a sickness, just as are baby-rape or wanting to be head of General Motors" (110). Stokely Carmichael, a leader of SNCC, stated that "the only position of women in SNCC is prone!" (Wallace, Black Macho 7). The black nationalist Maulana Ron Karenga, meanwhile, wrote that: 
What makes a woman appealing is femininity and she can't be feminine without being submissive. A man has to be a leader ... there is no virtue in independence. Black women should remember this. The role of a woman is to inspire her man, educate their children and participate in social development ... We say male supremacy is based on three things: tradition, acceptance, and reason. Equality is false; it's the devil's concept. Our concept is complimentary. (qtd. in Berkeley Art Center 71)

Karenga's writings supporting male supremacy and gender inequality convey contemporary male notions about black women, denying them agency in the Black Power movement. Less infamous for foul treatment of women, Amiri Baraka stated that: "we do not believe in the 'equality' of men and women, we cannot understand what the devilishly influenced mean when they say equality for women. We could never be equals, nature has not provided thus" (Watts 338). This consensus is also apparent in black film. Clearly, the dominant rhetoric among black men in the Black Power struggle was homophobic and sexist in nature. The instances in which gay liberation was tolerated referred specifically to white male homosexuality, overlooking the possibility of gay black men and, in most cases, completely ignoring black lesbianism.

While a few scholars (Hankin, Sims, Dunn and Lawrence especially) focus on lesbian relations in Foxy Brown and Cleopatra Jones, they do not extend their study more broadly to the female relations and anti-sisterhood present in these films and in Coffy, Black Mama, White Mama, Sheba Baby, and others. Foxy, Cleopatra, and Coffy work alone, and in almost every case rely on men for aidsupport. Furthermore, many of these films feature female antagonists and result in a final woman on woman fight scene between women, again denying characters female solidarity.

Black women struggled with both race and gender expectations in the 1960s and 1970s. The simultaneous timing of the Black Power and women's liberation movements allowed black men, and some women, to treat race and gender as two mutually exclusive categories so that race was privileged over gender (as exemplified by Dobson in the introductory quote). Thus, a gendered power structure was prevalent in Black Power movements that made men the warriors, while women were assigned to supporting roles in what became a male-dominated struggle for revolution (Brown 191). In fact, women were certainly aware of sexism in the movement, but contrary to many white women who were actively embracing second wave feminism as a form of resistance, black women "went right on trimming [their] afro[s], having [their] babies for the revolution" (Wallace, Black Macho 11). According to Elaine Brown, who became chairwoman of the Black Panther Party after Newton fled in 1974, many black women felt forced to denounce feminism as a bastion of middle-class whites and, as a result of the pressure to fully identify with race, were unable to actively fight against gender discrimination (367).

In 1965, the widely circulated Moynihan Report stated that "a fundamental fact of Negro American family life is the often reversed roles of husband and wife ... Negro husbands have unusually low power" (30). ${ }^{3}$ The report clearly identified black men as the true victims of racism and also of abnormal family structures in which men and women were systematically alienated from their "traditional" roles due to single black motherhood and the role of women as financial leaders of black households. This, however, was only a small fraction of the problem, as shown 
by the careful consideration black female intellectuals have given to the dilemma of black masculinity. Patricia Hill Collins posits that depictions of aggressive black masculinity in mass media "seem designed to refute accusations that black men are 'weak' because they cannot control black women" (189). She also suggests that while white men exercised violence through their own authority (in military and police forces), black men, lacking political and economic power, "use ... their bodies, physicality and a form of masculine aggressiveness" to assert supremacy (190). Safiya Buhkari goes further and looks to early slave conditions, theorising that:

Having been deprived of our culture, we began to take on the persona of our slave masters, filling the void of our lost culture with the slave culture that was foisted upon us. This is the root of sexism that is plaguing our communities today. Unlike the sexism characteristic of the white community, the sexism of the black community has its basis in racism and self-hate. (54)

This idea was further elaborated by bell hooks who argued that "blaming black women ... makes it possible for black men to negotiate with white people in all areas of their lives without vigilantly negotiating those interactions" (107). It is possible that male Black Power leaders, by blaming their plight on black women (instead of racist institutions) and limiting the formation of female solidarity in popular media - as exhibited in Coffy, Foxy Brown, Cleopatra Jones, and other films - essentially strengthened these institutions by adopting sexism as a product of white supremacist and capitalist patriarchy to improve their own chances of attaining power. By minimising women's identification with other women in these films, action heroines became symbols of Black Power, not women's liberation. Thus, black women within the Black Power structure were victims of racism and patriarchy, both externally and internally, despite official reports that stated otherwise.

Observing Black Power views of gay and lesbian liberation makes it clear that a dominant philosophy advocated against black lesbianism and proved to be overtly sexist and homophobic. While many groups prioritised black and white male camaraderie and solidarity (such as SNCC and NAACP: National Association for the Advancement of Colored People), black and white female companionship was suppressed. When asked about the breakup and transformation of the black liberation struggle, Angela Davis posited: "It was the inability to address questions of gender and sexuality that also led inevitably to the demise of many organizations", and that "women were responsible for a vastly disproportionate amount of work in a struggle constructed as one for the freedom of "the black man" ("Coalition Building Among People of Color" 309). Within this context we can observe the way gendered and racial politics played out within black action films.

\section{Representations of Racialised Lesbianism and Segregated Sisterhood}

Between 1973 and 1975, films such as Coffy, Foxy Brown and Cleopatra Jones starring Grier and Dobson introduced leading black women into the predominantly male blaxploitation genre. These women paradoxically performed hyper-femininity and hyper-masculinity within cinematic spaces, simultaneously acting as lethal action heroines and sex objects. The social spaces within these films expressed the borders of black and white femininity but still met the 
demands of a young black male audience as their plots focused on revolutionary vengeance and female nudity. Directors sold a racialised lesbianism that was inherently linked to the binary struggle between good and evil that categorised white women as lesbians and black women as straight. Morality, sexuality and race intersect and overlap in these films in various instances that expose a directorial interest in pleasing viewers which Guererro identifies as a "predominantly black, inner-city, adolescent male audience" (98). It is also important to note that most of the directors of the films in question were white men, with the exceptions of Filipino directors Eddie Romero and Cirio H. Santiago. It is useful, then, to think about the directorial implications and benefits of suggesting such dualistic notions of race, sexuality and morality.

Released in 1973, Black Mama, White Mama follows a narrative of two women (played by Grier and Margaret Markov) who are chained together while being transferred between women's penitentiaries. During their trip, replete with sexualised catfights and skimpy wardrobes, the two escape and journey across an island. The anti-hero from whom they escape, Matron Densmore (Lynn Borden), acts as a salacious lesbian prison guard who drinks too much and demands sex from new female inmates, happily beating those who refuse. Borden's character is villainised through her actions as a drunk and lesbian with uncontrollable and overt sexual urges. Here, the filmic space sets up a rivalry that is simultaneously racially, sexually and morally charged.

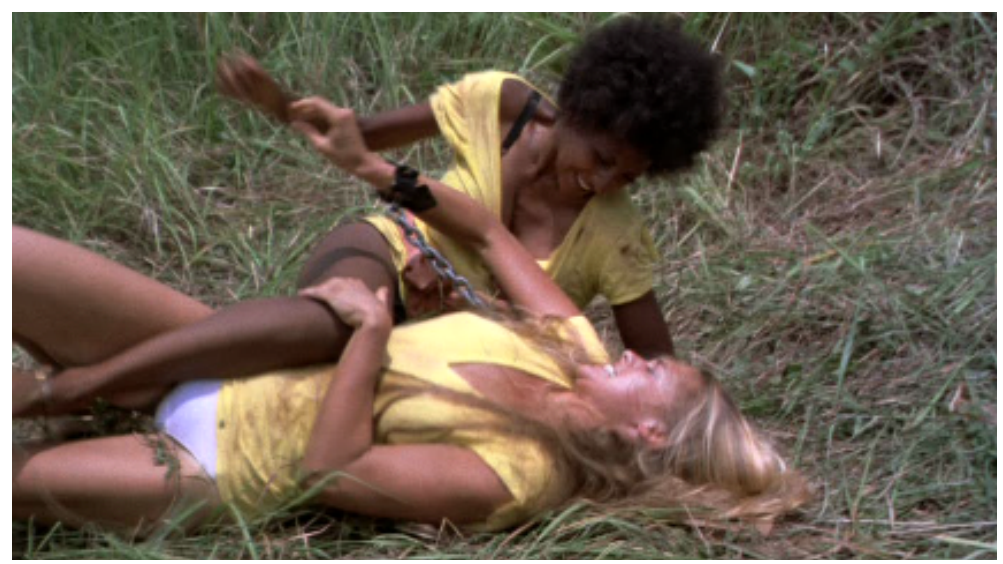

Bound together by chains, Lee (Pam Grier) and Karen (Margaret Markov) brawl over their next move after escaping from the women's penitentiary in Black Mama, White Mama (Eddie Romero, 1973).

A similar binary representation of homosexuality and heterosexuality exists in Cleopatra Jones. The film's narrative follows Jones, a United States special agent dedicated to arresting drug lords, who also works as a fashion model to disguise her government affiliation. Her archenemy is a sex-crazed white lesbian named Mommy (Shelley Winters) who controls a bevy of young women who cater to her every need. Shelley Winters's work in the film marks a shift in her career, exposing the ways in which certain aging stars dealt with the changing terms of the Hollywood system (Morrison 121). Acting in a wide range of films throughout the late 1940s, 1950s and 1960s, Winters won Academy Awards for both The Diary of Anne Frank (George Stevens, 1959) and A Patch of Blue (Guy Green, 1965) and established her credibility with films such as A Double Life (George Cukor, 1947), A Place in the Sun (George Stevens, 1951) and 
Lolita (Stanley Kubrick, 1962). By the 1970s, Winters, by now in her fifties, began embracing increasingly campy performance roles, starring in Bloody Mama (Roger Corman, 1970), What's the Matter with Helen? (Curtis Harrington, 1971) and Who Slew Auntie Roo? (Curtis Harrington, 1972). Her role as Mommy in Cleopatra Jones seems less surprising in this context. Nonetheless, and as James Morrison points out, Winters's seemingly unusual performance in blaxploitation can be assessed as her reluctance to disappear like many aging actors in the 1970s (121-37). In Cleopatra Jones, Mommy is represented as evil, sadistic, and sexually rampant; she is constantly flirting and making crude remarks to her female servants. She acts as the perfect anti-hero to Jones; her exaggerated gender transgressions serve to further legitimate a separation between the characters.

In the film's 1975 sequel, Jones is again challenged by a white lesbian villain ambiguously referred to as "The Dragon Lady" (Stella Stevens). Stevens's character heads an underground drug empire and fights Jones who attempts to save two government agents who have been taken hostage. Spectators are quickly made aware of The Dragon Lady's sexual preferences as the character is first introduced after emerging from what is presumably a lesbian sex orgy. The recurring theme of good versus evil, black versus white and straight versus gay permeates the narrative of the film and structures relationships between characters.

In 1973, Jack Hill directed Coffy, which also featured Grier, but this time (and for the first time in her career) she acted in the leading role as a powerful action heroine. The actress plays a nurse by day and vigilante by night, who seeks justice for her younger sister whose life was destroyed by involvement with the local drug underworld. Throughout the film, Grier has no female friends and relies instead upon her boyfriend (Booker Bradshaw), who proves to be unfaithful and corrupt. The film does not feature a white, lesbian villain but an overall lack of female camaraderie is apparent. For example, in order to gain access to powerful men in the drug trade, Coffy goes undercover as a prostitute. Her relationships with other women in the film are characterised by hatred and jealousy, as evinced in a vicious catfight that develops between the prostitutes where Coffy reveals the razor blades hidden in her Afro. The fight begins as a personal confrontation between Coffy and Meg (Linda Hayes) competing for the attention of their pimp and prospective clients. It devolves to include all the women present including black and bi-racial characters. Coffy fights with (and disrobes) women regardless of race suggesting a lack of race-based solidarity. One character stands out as being particularly resilient; she wears a red jumpsuit and sports an Afro. Though nameless in the film, her identity is revealed in the end credits as "Julia", played by Peaches Jones, a bi-racial actress who would appear again in Foxy Brown. I argue here that she exists within Coffy to reinforce the notion that sisterhood or any sense of female companionship, even race-based, is non-existent. 


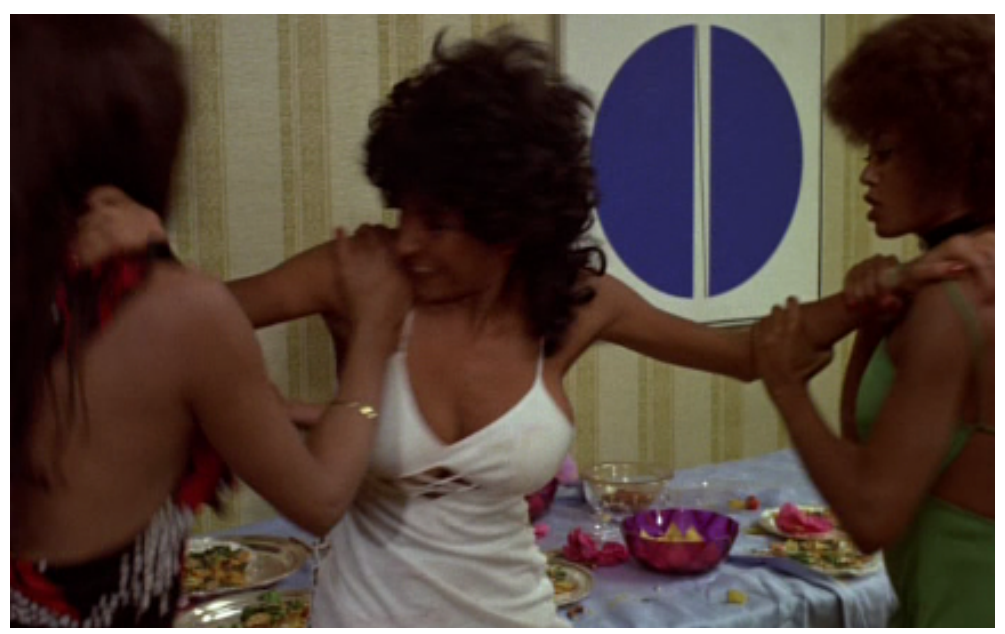

Disguised as a prostitute, Coffy (Pam Grier) fights off two women during a client party in Coffy (Jack Hill, 1973).

In 1974, Jack Hill cast Grier again as a lethal heroine in what became her best-known film, Foxy Brown. This time, Grier's Foxy seeks revenge for her government-agent boyfriend who has been killed by drug lords. She infiltrates the drug company (which fronts as a modelling/prostitution agency) by posing as a call girl. Again, themes of anti-sisterhood emerge throughout. Brown's arch-rival and head of the drug company responsible for killing her boyfriend is a Ms. Katherine (Kathryn Loder). Ms. Katherine and Brown exchange bitter glances from their first encounter up until the film's final moments. Though Ms. Katherine does not fall into the typical lesbian villain persona, an inherent female antagonism is notable between the two women. However, the film still manages to enforce an unnecessary disconnect between straight and gay women in a scene where Grier and her only friend, Claudia (Juanita Brown), enter an all-female gay bar and are surrounded by white lesbians. Significantly, the characters have no apparent reason within the narrative to enter the bar (they are indirectly fleeing an enemy but do not realise they have entered a lesbian bar until confronted). If the intent of the scene was to show that the characters were fleeing, they could have entered any other social space; the use of the lesbian bar functions on a deeper level to highlight race and sexuality as contentious factors in forming female solidarity. White lesbian women are juxtaposed with black straight women in the film, with clothing, accessories and attitudes differentiated visually and rhetorically. They are androgynously dressed with baseball caps and plaid button-ups, taking an aggressive stance while black straight women are hyper-femininely dressed, exposing cleavage and midriff, and only fight back when threatened. Characters are divided based on race and sexuality as well as fashion and attitude: the white lesbian women perform the stereotypes of what white men believe lesbians should look like (as defined by early 1970s gender constructions which relied heavily on notions of lesbians as either butch or femme) while black straight women are performing stereotypes in tune with the role of the jezebel (an essentialist portrayal of black women as having excessive and uncontrollable sexual appetites). The original function of the jezebel stereotype was, as Patricia Hill Collins put it, "to relegate all black women to the category of sexually aggressive women, thus providing a powerful rationale for the widespread sexual assaults by white men typically reported by black slave women" (82). Foxy Brown thus legitimises a separation based on race and sexuality by relying on established stereotypes that place an emphasis on physical appearance and behaviour. 


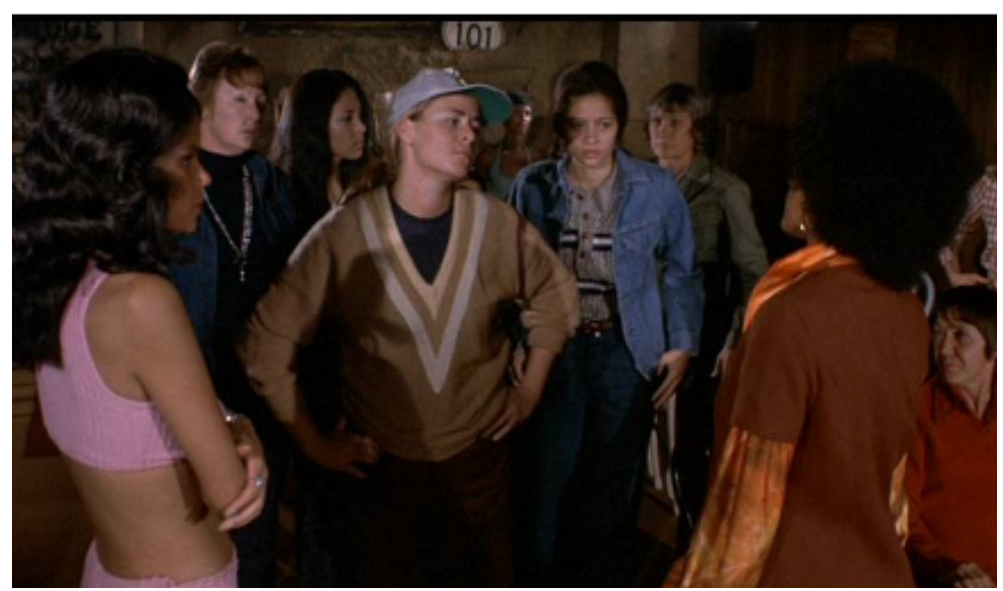

A group of women stop Foxy (Pam Grier) and Claudia (Juanita Brown) as they try to leave the lesbian bar in Foxy Brown (Jack Hill, 1974).

The film berates lesbianism and deems gay women unattractive, masculine, aggressive and sexually charged. The women divide themselves before the fight, and a single mixed-race character positions herself at the centre of the frame and quietly pleads with the leader of the lesbian/white side stating, "Leave her alone, Jackie, they're friends of ours". Though she remains nameless in the film, the character is identified in the credits as Barbara, played again by Peaches Jones. As a mixed-race character in the lesbian bar scene she acts as a crucial mediator between the two sides, signifying her ability to relate to and befriend black women because of her mixed heritage. Her placement within the frame (between the black and white characters) seems intentional given her racial affiliation with both sides. After her contestation of the fight, Barbara is aggressively shoved out of the conversation by Jackie (Stephanie Epper), one of the butch lesbian leaders. It seems plausible that Barbara, as a bi-racial character, functions in the scene to suggest that even within the designated categories of women in the film (black, white, straight, lesbian, femme, butch, villain, heroine, etc.) female alliances can exist only minimally and on a superficial level. Jones's characters act to debunk conceptions of inherent female solidarity in both Coffy and Foxy Brown. In the film, the character is not mentioned again and neither is lesbianism.

William Girdler's 1975 Sheba Baby exposes the same techniques that have tended to racially divide women. Once again, Grier leads the cast as a private detective who returns home to Kansas in order to protect her father from mobsters, but the film marks the beginning of a decline in her career as a blaxploitation actress. In Sheba Baby, Grier and a white female character start a fight during a boat party. Their rivalry begins through a series of contentious glances as they compete for a particular male character's attention. A fight ensues as Grier purposefully taps her cigarette ashes onto her opponent's shoulder. The quarrel entertains male (and female) spectators and exposes her undercover plot. This display of female hostility does not serve a purpose in the film except to portray women as jealous, dramatic and inherently antagonistic. 


\section{Who's Got the "Reel" Power?}

Women are presented in Grier and Dobson's films (specifically Black Mama, White Mama, Foxy Brown, Coffy, Cleopatra Jones, Cleopatra Jones and the Casino of Gold and Sheba $B a b y)$ as incapable of forming productive relationships with one another despite at times sharing common interests. Further scholarship is necessary in order to regard the female antagonisms in these films as instrumental to the limiting of real female coalition building at a time when women's liberation threatened male domination. These films are reflective of their time as signifiers of the problem of gender inequality. Furthermore, feminine and masculine representations in blaxploitation cinema shed light on dominant 1960s and 1970s Black Power groups and speak to sexist ideologies in the Black Power structure that turned women away from a masculine version of empowerment and, in some ways, crippled the movement at a time when women were needed most.

Popular representations of lesbianism and (anti)sisterhood within blaxploitation cinema reflect a dominant social view of American lesbianism as white, while straight women are consistently represented as black. These films allowed black women power and a voice and, as Sims argues, were liberating for many black women who encountered similar daily struggles ("From Headscarves to Afros" 26). However, these spaces also constricted black and white female identities by offering limited and contested relationships between women, exaggerating their distinctive qualities, to devalue the formation of gender-based solidarities. Female character identities were bifurcated and presented simply as good or evil, black or white, straight or gay, and feminine or butch. These identity constructions were used to illustrate the impossibility of alliance between characters with differing attributes. Questions must be raised as to the unique solitude of these female characters that existed within a setting where sisterhood was prohibited and lesbianism vilified.

A common trope is notable throughout Grier and Dobson's films, particularly in the context of the contemporary Black Power and women's liberation movements. I argue that these films, which were supposed to provide "reel" power for women, actually empowered men who benefited from a message of anti-sisterhood especially as the women's liberation movement flourished. While female tensions did already exist between Black Power and women's liberation activists (as asserted by Dobson and Brown), I posit that female relationships in these films were purposefully constructed to please a male audience anxious that female solidarities would threaten male domination. The casting of black women as powerful action heroines allowed female spectators to overlook the positioning of women against one another and instead celebrate their new cinematic authority. In observing women in blaxploitation cinema, it is important to ask: who's got the "reel" power? That is, who imagines these spaces that limit female solidarity and coalition or, rather, who are these spaces imagined for? It seems that the

answer is not white or black women but rather men who felt threatened by women's increasing power. 


\section{Notes}

${ }^{1}$ For a concise overview of the problems associated with the term blaxploitation as articulated by some of the actors and actresses within the genre, see Sims, "From Headscarves to Afros".

${ }^{2}$ In a similar vein, Get Christie Love! also features female rivalry. Directed by William Graham, the telemovie was so popular that it was made into a television show which ran for a year in 1974-75. While Sims argues that Graves's character does not fit the typical role of the exploited black heroine and therefore the film should not be deemed blaxploitation, it is still necessary to include it for the purpose of this argument which targets issues of female camaraderie in black films of the 70s (Women of Blaxploitation 111). The plot of the film follows Christie Love (Teresa Graves), a detective who is assigned to infiltrate and break up a drug ring. In the process, Love meets Helena Vargas, the girlfriend of a suspected drug lord. While their relationship is initially divisive, the two forge a friendship moments before Vargas dies. This brief instance of female camaraderie is fleeting and does not imply a coalition between the two women; Love uses Vargas for information and Vargas uses Love to see her long lost son. T.N.T. Jackson, a lesser known film featuring actress Jeannie Bell, also follows a trend of representing antagonistic womanhood. Jackson encounters a female gun moll named Elaine (Pat Anderson). The two continually exchange insults throughout the film and at one point engage in a karate fight. Although Elaine is not a lesbian or the main villain, she represents a white female character who is incompatible with Bell's character. Even after their brawls when Elaine exposes her secret identity as a special agent, the two never become particularly friendly.

${ }^{3}$ Written by Daniel Patrick Moynihan-Assistant Secretary of Labor in the Lyndon Johnson administration-The Moynihan Report (alternatively referred to as "The Negro Family: The Case for National Action") was a sociological investigation of poverty levels amongst AfricanAmericans in early 1960s America. Controversially, Moynihan identified a comparative absence of nuclear families as a singular impediment to the economic and political advancement of the black community.

\section{Works Cited}

Benshoff, Harry and Sean Griffin. Queer Images: A History of Gay and Lesbian Film in America. New York: Rowman \& Littlefield Publishers, Inc., 2006. Print.

Berkeley Art Center, The Whole World is Watching: Peace and Social Justice Movements in the 1960s and 1970s. Berkeley: Berkeley Art Center Association, 2001. Print.

Black Mama, White Mama. Dir. Eddie Romero. MGM, 1973. Film

Bloody Mama. Dir. Roger Corman. Twentieth Century Fox, 1970. Film. 
Bogle, Donald. Brown Sugar: Eighty Years of America's Black Female Superstars. New York: Harmony Books, 1980. Print.

Boyz $n$ the Hood. Dir. John Singleton. Columbia, 1991. Film

Brody, Jennifer DeVere. "The Return of Cleopatra Jones". Signs: Journal of Women and Culture 25.1 (1999): 91-121. Print.

Brown, Elaine. A Taste of Power: A Black Woman's Story. New York: Doubleday, 1992. Print.

Bukhari, Safiya. The War Before: The True Life Story of Becoming a Black Panther. New York: Feminist Press, 2010. Print.

Cleaver, Eldridge. Soul on Ice. New York: Dell Publishing, 1968. Print.

Cleopatra Jones. Dir. Jack Starrett. Warner Bros., 1973. Film.

Cleopatra Jones and the Casino of Gold. Dir. Charles Bail. Warner Bros, 1975. Film.

Coffy. Dir. Jack Hill. MGM, 1973. Film.

Davis, Angela. "Coalition Building Among People of Color". The Angela Y. Davis Reader. Ed. Joy James. Oxford: Blackwell Publishing, 1998. 297-306. Print.

Dead Presidents. Dir. Allen Hughes. Hollywood Pictures, 1995. Film.

The Diary of Anne Frank. Dir. George Stevens. Twentieth Century Fox, 1959. Film.

Dolemite. Dir. D’Urville Martin. C.I.E., 1975. Film.

Do the Right Thing. Dir. Spike Lee. 40 Acres \& A Mule, 1989. Film.

A Double Life. Dir. George Cukor. Universal, 1947. Film

Dunn, Stephanie. "Baad Bitches” and Sassy Supermamas: Black Power Action Films. Urbana: University of Illinois Press, 2008. Print.

Foxy Brown. Dir. Jack Hill. MGM, 1974. Film.

Gates, Philippa. Detecting Women: Gender and the Hollywood Detective Film. Albany: State University of New York Press, 2011. Print.

Get Christie Love!. Dir. William A. Graham. Universal TV, 1973. Film. 
Guerrero, Edward. Framing Blackness: The African American Image in Film. Philadelphia: Temple University Press, 1993. Print.

Hankin, Kelly. The Girls in the Back Room: Looking at the Lesbian Bar. Minneapolis: University of Minnesota Press, 2002. Print.

Hill Collins, Patricia. Black Sexual Politics: African Americans, Gender, and the New Racism. New York: Routledge, 2004. Print.

Holmlund, Chris. "Wham! Bam! Pam! Pam Grier as Hot Action Babe and Cool Action Mama". Quarterly Review of Film and Video 22.2 (2005): 97-112. Print.

hooks, bell. Black Looks: Race and Representation. New York: Routledge, 1992. Print.

Karenga, Maulana. The Quotable Karenga. Eds. Clyde Halisi and James Mtume. Los Angeles: US Organization, 1967. Print.

Keeling, Kara. The Witch's Flight: The Cinematic, the Black Femme, and the Image of Common Sense. London: Duke University Press, 2007. Print.

Klemesrud, Judy. "Tamara Dobson-Not Super Fly but Super Woman”. New York Times 19 Aug. 1973: 117. Print.

Lawrence, Novotny. "A Cinema of Contradictions: Gay and Lesbian Representation in 1970s Blaxploitation Films". Queers in American Popular Culture 1. Ed. Jim Elledge. Santa Barbara: Praeger, 2010. 103-23. Print.

---. Blaxploitation Films of the 1970s: Blackness and Genre. New York: Routledge, 2008. Print.

Lolita. Dir. Stanley Kubrick. MGM, 1962. Film.

Mask, Mia. Divas on Screen: Black Women in American Film. Urbana: University of Illinois Press, 2009. Print.

Morrison, James. Hollywood Reborn: Movie Stars of the 1970s. New Jersey: Rutgers University Press, 2010. Print.

Moynihan, Daniel Patrick. "The Negro Family: The Case for National Action". Washington: Government Printing Office, 1965. Print.

New Jack City. Dir. Mario Van Peebles. Warner Bros , 1991. Film.

Newton, Huey P. To Die for the People: The Writings of Huey P. Newton. Ed. Toni Morrison. New York, Random House, 1972. Print. 
A Patch of Blue. Dir. Guy Green. MGM, 1965. Film.

Peiss, Kathy. Hope in a Jar: The Making of America's Beauty Culture. New York: Metropolitan Books, 1988. Print.

A Place in the Sun. Dir. George Cooper Stevens. Paramount, 1951. Film.

Robinson, Cederic J. "Blaxploitation and the Misrepresentation of Liberation". Race and Class 40.1 (1998): 1-20. Print.

Reid, Mark. Redefining Black Film. Berkeley: University of California Press, 1993. Print.

Schubart, Rikke. Super Bitches and Action Babes: The Female Hero in Popular Cinema, 19702006. Jefferson: McFarland \& Co., 2007. Print.

Shaft. Dir. Gordon Parks. MGM, 1971. Film.

Sheba Baby. Dir. William Girdler. MGM, 1975. Film.

Sims, Yvonne D. Women of Blaxploitation: How the Black Action Film Heroine Changed American Popular Culture. Jefferson: McFarland and Company, Inc., 2006. Print.

---. "From Headscarves to Afros: Redefining African-American Femininity and Empowerment in Selected 1970s Black Action Films". Ethnic Media: Taking Control 3. Ed. Guy T. Miles and Alice Tait. Iowa: Kendall/Hunt Dubuque (2005): 213-29. Print.

Springer, Kimberly. "Divas, Evil Black Bitches, and Bitter Black Women: African American Women in Postfeminist and Post-Civil-Rights Popular Culture". Interrogating Postfeminism: Gender and the Politics of Popular Culture. Ed. Yvonne Tasker and Diane Negra. London: Duke University Press, 2007: 249-76. Print.

---. Living For The Revolution: Black Feminist Organizations, 1968-1980. Durham: Duke University Press, 2005. Print.

---. "Waiting to Set It Off: African American Women and the Sapphire Fixation". Reel Knockouts: Violent Women in the Movies. Ed. Martha McCaughey and Neal King. Austin: University of Texas Press, 2001: 172-99. Print.

Super Fly. Dir. Gordon Parks Jr. Sig Shore Productions, 1972. Film.

Sweet Sweetback’s Baadasssss Song. Dir. Melvin Van Peebles. Yeah, 1971. Film

T.N.T. Jackson. Dir. Cirio H. Santiago. HPS Productions, 1974. Film. 
Van Deburg, William. Black Nationalism: From Marcus Garvey to Louis Farrakhan. New York: New York University Press, 1997. Print.

Waddell, Calum. Jack Hill: The Exploitation and Blaxploitation Master, Film by Film. Jefferson: McFarland, 2009. Print.

Wallace, Michele. Dark Designs and Visual Culture. London: Duke University Press, 2004. Print.

---. Black Macho and the Myth of the Superwoman. New York: Dial Press, 1979. Print.

---. “A Black Feminist's Search for Sisterhood”. The Village Voice 28 July 1975): 5-12. Print.

Watts, Jerry Gafio. Amiri Baraka: The Politics and Art of a Black Intellectual. New York: New York University Press, 2001. Print.

What's the Matter With Helen? Dir. Curtis Harrington. Filmways Pictures, 1971. Film

Whoever Slew Auntie Roo? Dir. Curtis Harrington. American International Productions, 1972. Film.

Wilkerson, Isabel. "Hollywood Shuffle: With White Men Calling the Shots, Black Women Have No Reel Power". Essence 27.11 (March 1997): 71-4; 129-32. Print.

Wlodarz, Joe. "Beyond the Black Macho: Queer Blaxploitation". Velvet Light Trap 53 (March 2004): 10-25. Print.

\section{Suggested Citation}

Seifert, Melissa DeAnn. "Who's Got the 'Reel' Power? The Problem of Female Antagonisms in Blaxploitation Cinema". Alphaville: Journal of Film and Screen Media 4 (Winter 2012). Web. ISSN: 2009-4078.

Melissa DeAnn Seifert is a second year Masters student in the Department of Art History at the University of Wisconsin-Milwaukee. She also currently works as a teaching assistant for an introductory film history course at the university. Her research interests include non-traditional art forms, visual culture and film media where she specifically aims to understand the politics of domination, subjugation and resistance. Within these frames, she deconstructs representations of women, gender relations and sexuality. 